\title{
CS-10 Uso del índice de Garcés en quemaduras pediátricas versus clasificación de Benaim en pacientes pediátricos como predictor de morbilidad
}

\author{
Garcés' index versus Benaim's classification in pediatric burns as a morbidity predictor \\ Julio R. Samayoa-Cuc
}

Facultad de Ciencias Médicas, Universidad de San Carlos de Guatemala, Guatemala

*Autor al que se dirige la correspondencia: jsamayoa51@hotmail.com

\section{Resumen}

as quemaduras de pacientes pediátricos en Guatemala representan el $15 \%$ de las consultas anuales a las emer-
gencias. No se cuenta con una herramienta modelo para la gradación adecuada de los niveles intermedios de
quemadura. El objetivo fue realizar la comparación entre el índice de gravedad de Garcés (Artigas/Minsal) y la
escala Benaim en pacientes pediátricos quemados del Hospital de Cuilapa, Santa Rosa en 2013, para establecer su
efectividad. Estudio descriptivo, retrospectivo que se llevó a cabo por encuesta, recabando los datos de los expe-
dientes luego del egreso. Se evidenció que la moda de género del grupo fue varón, con edad $<2$ años, afectando
el $10 \%$ de su superficie corporal, siendo la quemadura de segundo grado superficial la prevalente. La estancia
intrahospitalaria promedio fue de 11 días. Los pacientes se evaluaron, según la escala pronóstica de Garcés, el cual
se calificó como riesgo moderado, pero comparando el mismo grupo con la escala de Benaim, como estándar, se
evidenció que se encuentra en el grupo I (leve). Al evaluar, los verdaderos negativos fueron el $51 \%$. Se determinó
el valor predictivo negativo el cual fue del $100 \%$, por lo que se evidencia la alta sensibilidad para descartar la
presencia de morbilidad en los pacientes más graves. Se recomienda continuar el estudio a mayor escala, y en un
futuro mejorar el proceso de clasificación de pacientes para disminuir el riego de morbilidad.

Palabras claves: Quemadura infantil, morbilidad, escaldaduras

\section{Abstract}

$\mathrm{B}$ urns on pediatric patients in Guatemala account for $15 \%$ of annual emergency consultations. At the moment there is no model tool for proper gradation of intermediate levels of burn. The aim was to compare the Garcés' index (Artigas/Minsal) and the Benaim's classification in pediatric patients with burnes at the Cuilapa Hospital, Santa Rosa in 2013, in order to establish their effectiveness. This is a descriptive, retrospective study that was carried out by survey, gathering the data of the files after the discharge. It was evidenced that the gender genre of the group was male, with less than two years old, affecting $10 \%$ of their body surface, being the second degree surface burn the prevalent. The hospital stay was 11 days on average. This group of patients was evaluated according to the Garcés predictive scale, which was classified as a moderate risk, but comparing the same group with the Benaim scale as a standard, it is evident that it is in group I (mild). When evaluating, the real negatives were $51 \%$. The negative predictive value was determined, which was $100 \%$, which is why it is evidenced the high sensitivity to rule out the presence of morbidity in the most severe patients. It is recommended to continue the study on a larger scale, and in the near future to improve the classification process of this group of patients to reduce the risk of morbidity.

Keywords: Child born, morbility, scalds 